\title{
Rethinking Death Education as Part of Public Health Policy
}

\author{
João Carlos Macedo ${ }^{1^{*}}$ \\ DOI: $10.9734 / \mathrm{bpi} / \mathrm{rdmmr} / \mathrm{v} 12 / 12549 \mathrm{D}$
}

\begin{abstract}
Death and dying are still taboo subjects in today's society. In most western countries, people die mostly in hospitals, surrounded by health professionals and high technology, but with no real humanisation of care. This transfer of death from the home to hospitals, which began in the 1960s of the last century, has brought social and cultural consequences for the way we deal with the end of life. We will have to save the work of some experts, like Elisabeth Kübler-Ross (1926-2004), to consider the need for death education. Based on the work of this paradigmatic author and other studies over time, we present a set of proposals for implementing death education as part of public health policy.
\end{abstract}

Keywords: Death; dying; education; public health.

\section{DEATH DENYING SOCIETY}

Although more is said about human death nowadays, it can be said that it remains a taboo subject. According to Barros de Oliveira, "[...] all taboos have fallen, like sex, but death today is more than ever forbidden to show anything obscene or pornographic [...]" [1]. This denial of death is inherent in the very performance of today's society, since "[...] technically it is admitted that we can die and take steps in life to preserve ours from misery. But truly, deep within ourselves, we do not feel mortals " [2]. The very "place" or "place" where one usually dies today, so different from the times when it once was, contributes to this sense of ignorance of death. Death as a life event has moved from the domain of the family to the domain of health technicians.

There were generations when the person died at home, said goodbye to the family, settled the last commitments of life and everyone watched this event in a deeply natural way. Today, and since the 1960 s, advances in resuscitation and medical intensivism have led to the hospitalisation of death. In some countries, these transformations have been so evident that today two thirds of Britons die in hospitals and $80 \%$ of deaths in the United States occur in various healthcare facilities [3]. This is a trend that also occurs in Portugal, where approximately $60 \%$ of deaths occur in hospital units [4-5].

This social transformation of the place of death has led to a progressive oblivion in the community context and even to its denial: [...] the reigning materialism and hedonism do not hold that the thought of death will disturb a growing consumerism of goods and pleasures, death is seen as a biological fact only and not as a profoundly human reality [1]. This "hidden" death - a term used by Ivan Illich - [6] and hospitalised death has repercussions on the health care of the person at the end of life, family members and health professionals who deal daily with terminally ill patients. Today it is consensual and several authors who have carried out field studies, the experience of suffering and loss may be adverse to the proper functioning of the immune system, accentuating the risk of disease and eventually precipitating towards death. As examples of problems with people who have lost loved ones, it also points to increased use of alcohol, drugs, the onset of depression and inability to work. It should also be noted that health professionals may experience various symptoms of stress if they are

${ }^{1}$ UICISA: E - Health Sciences Research Unit, JusGov - Research Centre for Justice and Governance, Portugal.
${ }^{*}$ Corresponding author: E-mail: jmacedo@ese.uminho.pt; 
permanently caring for terminally ill people [7]. All these facts lead us to reflect on the death-health binomial and the current uprooting death in community life.

People die in hospital, alone, surrounded by white coats, and often cannot face and introduce death into their horizons because they never had the opportunity to discuss it during their lives; on the other hand, family members and friends, also because they do not include death as an integral part of life, may develop prolonged and life-threatening illnesses. In contact with terminally ill patients and their relatives, there is currently a certain degree of distancing of the patient, a certain disorientation of the family and even a coldness in the attitudes of certain professionals when confronted with death.

\section{DEATH EDUCATION THROUGH THE WORK OF ELISABETH KÜBLER-ROSS}

In the path of thanatology, there is a name that is a classic reference in this field: Elisabeth KüblerRoss (1926-2004). Kübler- Ross was a Swiss psychiatrist, later to become a US citizen, who soon became interested in working with those at the end of life, beginning her investigations at the end of the sixties of the last century. Since that time, in addition to accompanying several hundred people at the end of their lives, she has produced more than a dozen books devoted to reflection on death and accompaniment at the end of life. Despite all the controversy about her work in the scientific world [78] her perspective leads us to the need to integrate death into life, making it clear that the dying are our best teachers of the meaning of death and life. On the other hand, death is considered, not as a failure of the medical forum, but as a natural and predictable process.

Besides alerting us to the need for a greater awareness of death itself, Kübler-Ross thought that accompanying the person at the end of their life would certainly change our perception of mortality. Prompted by the author's thoughts, we found that this inclusion of death in the discourse should undergo an education about death in order to be more "natural" and as an inescapable fact of life. It is concluded that Kübler-Ross was a legitimate advocate for the "falling of the wall" of death that society. The concealment of death in social life, the hidden place, led to the current situation of the person being unable to deal in a "natural" way with the end of life. As Santos tells us in this respect: "Hiding suffering, death and dying is not healthy for a society. [...] Hardly a society that ostracizes the idea of death learns to care for and respect its elderly or to understand and respect the grief felt by someone who has lost a friend or family member" [9]. Now Kübler-Ross has vehemently fought this social problem, and throughout her work, the warning for a greater social awareness of death is clearly evident. Just by pointing to the seminars On Death and Dying and the workshops she has held, we already have two clear examples of contributions to a greater social awareness of death. Kübler-Ross had the great merit of breaking the conspiracy of silence around death that had settled in the social environment in general and among health professionals in particular. For her, any important aspect of people's lives should be the object of attention and discussion, whether it be birth, illness or death. Only in this way would it be easier, or less painful, to deal with many of the problems people have when they lose someone or fall victim to fatal illnesses, being seen as part of life. From his childhood days, through her medical training and, with more from the 1960s on wards, when she spent time at Billings Hospital running the On Death and Dying seminars, Kübler-Ross embarked on a life-oriented issue of death, rather than approaching it and accompanying those in the final stages of life. In her performance, one comes across a constant note: meeting those who are dying and acting there as empathetically as possible. It is this fundamental attitude that leads her not to forget the patient's family or the specificity of death in children, while also trying to give her humanitarian contribution to AIDS patients. It is this fundamental idea of not being overcome by the fear of death, whatever form it takes, let alone abandoning death, that led Kübler-Ross to act in various areas of death, trying to bridge the educational gap about death in our societies.

Although some of her conclusions do not meet all scientific rules, her work created conditions for others to become aware of the problems in the thanatological field and, at the same time, it also contributed to a greater empowerment of the terminally ill, in other words, it can be said that KüblerRoss' work helped the terminally ill to gain greater credibility with society and to acquire a new status with health professionals. 
By drawing attention to the main problems that were present in the treatment of terminally ill patients, Kübler-Ross denounced the dehumanisation of the situation and declared that the terminally ill person retains all his dignity, we can learn a lot from him if we approach his bedside and follow him to the end. It is here, in this follow-up, that Kübler-Ross intends to make professionals in particular, and society in general, aware of the special needs of the patient at the end of his life. In this sense, the author tries, as I mentioned earlier, through her work, to break the social silence about death, using the terminally ill, their stories to make society aware of their most pressing problems. However, Kübler-Ross did not forget another important facet, closely related to the terminally ill patient, the needs for accompaniment from family and friends. Let us say that there is a triple front in Kübler-Ross to break the taboo of death and reintroduce the topic into social discourse: a) denunciation of the state of social denial of death; $b$ ) awareness of the needs of the terminally ill; c) awareness of the needs of the relatives and friends of the terminally ill. Moreover, Kübler-Ross, through her seminars, workshops she gave and the many lectures she delivered, was spreading these ideas, contributing to a more humanising vision of the terminally ill patient and, at the same time, boosting end-of-life healthcare through the birth of palliative care. Dennis Klass, Professor of Religious Studies at Webster University, St. Louis, Missouri, and former assistant to Kübler-Ross at the On Death and Dying seminars at the University of Chicago, supports this idea, stating that:

"The five stages Kübler-Ross speaks of in his first book, in which he warns of the need to listen to those who are dying - whose life experiences can be of great use to today's society denying death - was clearly a motivating factor for the founding of many back hospitals, and for the establishment of programs to support the dying and their family and friends." [10]

The aim of palliative care is to achieve the best possible quality of life for the patient and his family [11]. From this perspective, it is clear that the work of Kübler-Ross has been a driving force behind the development of palliative care, especially in the United States of America. The author herself corroborates the idea, stating that:

In the United States, Hospice of New Haven in Connecticut was the first to open its doors to a home care programme to give people the total patient care that is needed when cure, active treatment, and life extension are no longer the goal. Since the opening of Hospice in New Heaven, we have been able to facilitate and encourage 55 other places in the United States to develop a hospice, and it is a rare state that does not have such a facility at least in the planning stages [12].

In a final and brief analysis, we state that Kübler-Ross was a pioneer because she sought in various ways to introduce death education, which we consider to be a facet of health promotion. As Charles Corr, Clyde Nabe and Donna Corr states: 'With Kübler-Ross (1969), death education seeks to show its relevance in all these ways: to the client who is dealing with death or bereavement; to the helper in his work-related role; and to the helper as a person in his own right [13]. Thus, it is concluded that their whole path tends to create conditions for death and those in the final stages of life are the subject of discussion, attention and, above all, truly incorporated into social life. The author intends to generate a healthier path not to reject death, but to see it as a part of life. Contact with experiences of death and the inclusion and discussion of death from childhood will contribute to seeing it as an integral part of life and will certainly help in the growth and maturation of the person [14]. As KüblerRoss wrote in her autobiography: "My parents did not shield me from life and death as it happened naturally, which allowed me to absorb the different circumstances as well as people's reactions" [15]. We can sum this up with a sentence:" If it is natural to die, why is it not natural to educate about and for death, to talk about one's own death and the death of others, and to teach (and learn) to live and die well? Is it not possible to have a pedagogy of death, which we could call thanatological education? The answer is not only that such an education is possible but also necessary for integral education" [1].

\section{DEATH EDUCATION AS PART OF PUBLIC HEALTH POLICY: SOME PROPOSALS}

Following the work started by Kübler-Ross and other specialists over time, there is still a need to (re)introduce death and dying in the social discourse. We share the idea of Kellehear that states: "... 
the need to make death education a public health priority, taking its place alongside all other public health campaigns that contribute to national health and well-being" [16]. Thus, we present some proposals for death education that could be inserted in a public health policy:

a) within the strategies that need to be implemented, the most urgent would be the introduction of the theme of death in school curricula, as a transversal subject, from the first years of school. This would necessarily help the integration of death from the earliest age. This idea is not original, since in other countries, such as the United States of America, Israel, Canada and Australia, there are some cases of integration of the theme of death in the school curriculum $[17,18,19]$.

b) there is also an imperative need to increase the number of hours of training on death and dying in the curriculum of future health professionals. Medical and nursing schools still have a few hours to study death and dying; $[13,18,20]$.

c) Implement death education programmes for health professionals who deal daily with dying patients; This measure will contribute to improving the quality of work of health professionals $[18,20,21,22]$.

d) Encouraging the formation of groups of volunteers willing to accompany terminally ill patients would be an interesting way of bringing people closer to the process of death, would help to identify the needs of patients and, above all, would break the silence surrounding death $[13,23]$.

e) Creating short courses on death and dying for adults could help to integrate death into life, decrease fear and anxiety $[13,17,23]$.

f) In countries where living will or advance care planning is legal, they can empower the citizen with drafting it. In other words, there is a need for policies to disseminate the living will, especially in the older population, to exercise autonomy and prevent futility treatments. Talking about the end of life with a trusted person is the first step to be able to write down the wishes / wishes to be fulfilled when the person is at the end of life $[23,24]$.

g) Finally, in some countries, the decriminalisation of assisted dying is being discussed. This is a unique opportunity to discuss the end of life in society. Regardless of the outcome, the educational process occurs when the community abandons the taboos and faces the problems $[13,25]$

It is a challenge for everyone to make efforts to make death education a reality and not just a rhetoric of some or simply an intention of others [25] As Wass states:" Death education can benefit all people, from childhood to old age. It is critical to helping professionals. Future death education for all populations, but especially these groups, needs to be broadened in scope and depth and provide opportunities for personal involvement" [19] The earlier the conditions for effective death education are created, the more easily we will face the end of life with some "naturalness" [16] As Quill states: "By exploring our hopes and fears about our own death, and by listening and learning from the stories about those who have directly faced death, we will hope to learn how to use medicine's power judiciously to achieve two of its most important objectives: prolonging a meaningful life and humanizing the process of dying" [26].

Probably many health problems will decrease if we see death as a natural and inevitable fact of life for every human being. Just as we have in the area of public health policy guidelines for the promotion of sexual health, healthy eating or promotion of physical activity, so it is also essential to assume death education as an area of public health that will lead to mental health gains in the population $[25,27]$ [26]. In the bereavement process, this internalisation of finitude is important so that the time of mourning is facilitated [27]. Especially in these times of the COVID-19 pandemic, when many people died alone and relatives and friends were not able to say goodbye, we need to bring to the public health agenda the implementation of measures that promote death education to achieve better health [25]. In the words of Kübler-Ross:

"It is hard to die, and it will always be so, even when we have learned to accept death as an integral part of life, because dying means giving up life on this earth. But if we can learn to view 
death from different perspectives, to reintroduce it into our lives so that it comes not as a dreaded stranger but as na expected companion to our life, then we can also learn to live our lives with meaning - with full appreacition of our finiteness, of the limits on our time here" [28].

\section{CONCLUSION}

We live in a society that denies death and this fact has consequences for individual and collective health because we lack the skills and capacities to deal with the last stage of life. Authors like Elisabeth Kübler-Ross give life to this greater good: to death education as something fundamental in the normal and healthy growth of any human being. Through this author and others who have researched the field of thanatology, we have come to the conclusion that there is a need to work in this direction: to (re)introduce the theme of death and dying in the community discussion and to present, in a pragmatic way, concrete proposals, which should be seen as a priority in public health policies.

\section{COMPETING INTERESTS}

Author has declared that no competing interests exist.

\section{REFERENCES}

1. Barros de Oliveira JH. Viver a morte - abordagem antropológica e psicológica. Coimbra: Livraria Almedina; 1998.

2. Ariès $P$. Western attitudes toward death from the middle ages to the present. Baltimore: The Johns Hopkins University Press; 1975.

3. Nuland SB. How We Die. Reflections of Life's Final Chapter. New York: Vintage Books; 1993.

4. Machado MC, et.al. A Morte e o Morrer em Portugal. Coimbra: Almedina; 2011.

5. Bárbara G, et.al. Epidemiological Study of Place of Death in Portugal in 2010 and Comparison with the Preferences of the Portuguese Population. Acta Médica Portuguesa. 2013;26(4):327334

6. Illich I. Limits to Medicine. Medical Nemesis: The expropriation of health. New York: Random House; 1976.

7. Corr A. Coping with dying: lessons that we should and should not learn from the work of Elisabeth Kübler-Ross. Death Studies. 1993;17:69-83.

8. Chaban MCG. The life work of Dr. Elisabeth Kübler-Ross and its impact on the death awareness movement. NewYork/Ontario: Edwin Mellen Press; 2000.

9. Santos LF. Eutanásia: para poder amar a vida até ao fim?. Interacções. 2003;4:25-58.

10. Klass D. Kübler-Ross, Elisabeth. In Howarth, G, Leaman, O, editors. Encyclopedia of Death and Dying.New York: Routledge. 2001;316-317.

11. WHO. Palliative Care; 2012. Available: http://www.who.int/cancer/palliative/definition/en

12. Kübler-Ross E. To live until we say good-bye. New Jersey: Prentice-Hall; 1978.

13. Corr CA, Nabe CM, Corr, D M. Death and Dying, Life and Living. California: Brooks / Cole Publishing Company; 1994.

14. Kübler-Ross, E. On death and dying. New York: Touchstone; 1969.

15. Kübler-Ross, E. The wheel of life: A memoir of living and dying. New York: Touchstone; 1997.

16. Kellehear A. Death Education as a Public Health Issue. In: Stillion J and Attig T (Eds.) Death, Dying and Bereavement: Contemporary Perspectives, Institutions and Practices. New York, USA: Springer Publishing. 2015;221-232.

17. Clark V. Education. In: Howarth, G, Leaman, O, editors. Encyclopedia of Death and Dying.New York: Routledge. 2001;192-195

18. Dickinson, G. End-of-life and palliative care issues in medical and nursing schools in the United States. Death Studies. 2007;31:713-726.

19. Wass H. A perspective on the current state of death education, Death Studies. 2004;28:4,303 DOI: $10.1080 / 07481180490432315$

20. Dadfar M, Lester D. The effectiveness of $8^{\mathrm{a}}$ model death education on the redution of death depression. A preliminar study. Nursing Open. 2009;00:1-5. 
Available: https://doi.org/10.1002/nop2.390 (open acess).

21. Cui $\mathrm{J}$, et al. What do nurses want to learn from death education? A survey of their needs. Oncology Nursing Forum. 2011;38(6):E402-E408.

22. Zhang H, Hu M, Zeng L, Ma M, Li L. Impact of death education courses on emergency nurses' perception of effective behavioral responses in dealing with sudden death in China: A quasiexperimental study. Nurse Education Today. 2020;85.

23. Macedo JC. Contribution to improve advance directives in Portugal. MOJ Gerontolology \& Geriatrics. 2020;5(1):27-30.

DOI: $10.15406 /$ mojgg.2020.05.00225

24. Sanderson C, Miller-Lewis L, Rawlings D, Parker D, Tieman J. "I want to die in my sleep"-how people think about death, choice, and control: findings from a Massive Open Online Course. Ann Palliat Med. 2019;8(4):411-419.

DOI: 10.21037/apm.2019.03.07. Epub 2019 Mar 28. PMID: 30943742.

25. Macedo JC. Death Education - An approach from the work of Elisabeth Kübler-Ross.Berlin: Lambert Academic Publishing; 2020.

26. Quill TE. Death and Dignity - Making Choices and Taking Charge. New York/London: WW. Norton \& Company; 1994.

27. Worden JW. Grief Counseling and Grief Therapy. A Handbook for the Mental Health Practitioner. New York: Springer Publishing; 2002.

28. Kübler-Ross, E. Death: the final stage of growth. New York: Touchstone. 1986;6. 
Recent Developments in Medicine and Medical Research Vol. 12 Rethinking Death Education as Part of Public Health Policy

Biography of author(s)

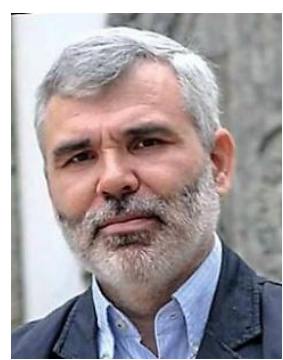

Mr. João Carlos Macedo

UICISA: E - Health Sciences Research Unit, JusGov - Research Centre for Justice and Governance, Portugal.

$\mathrm{He}$ is an Adjunct Professor at the Nursing School of the University of Minho - Portugal, and teaches Ethics and Deontology, Bioethics and Community Health Nursing. He obtained his Specialist Title in Nursing from the University of Minho in 2014; Master in Health Education in 2004 from the University of Minho; Degree in Community Nursing in 1997 by the Portuguese Catholic University; Bachelor in Nursing from the Calouste Gulbenkian School of Nursing -Braga, Portugal. He is currently a $\mathrm{PhD}$ student in Bioethics at the University of Porto (2020). He is currently a collaborating researcher at the Health Sciences Research Unit: Nursing (UICISA:E) and at the Research Center for Justice and Governance (JusGov) - research group on Human Rights - Law School - University of Minho. He has published 10 articles in specialized journals and 2 books: Educar para Morte (2011). Coimbra: Almedina; Death Education (2020). Berlin: LAP LAMBERT Academic Publishing. His profile link : https://www.cienciavitae.pt/portal/en/BE1D-216B-21D6

(C) Copyright (2021): Author(s). The licensee is the publisher (B P International).

DISCLAIMER

This chapter is an extended version of the article published by the same author(s) in the following journal. MOJ Gerontol Ger, 4(6):276-278, 2019. 